\title{
EFFECTIVENESS OF INVESTMENTS \\ IN MUNICIPAL WASTE MANAGEMENT IN POLAND \\ IN THE CONTEXT OF GOALS OF THE CIRCULAR ECONOMY
}

\author{
AGNIESZKA CIECHELSKA
}

Wrocław University of Economics, Faculty of Economic Sciences, POLAND

e-mail: agnieszkaciech@poczta.onet.pl

RECEIVED

ACCEPTED

JEL

CLASSIFICATION

KEYWORDS

ABSTRACT
18 January 2018

2 September 2018

Q53, Q58

circular economy, municipal waste management, municipal investment efficiency

Municipal waste management has become one of key areas for a circular economy. The European Union has founded its new strategy (Europe, 2003) on such an approach: wastes are raw materials and hence, it is possible to limit acquisition of original resources. To achieve the goal, a relevant sequence of proceedings regarding wastes has been approved: prevention, preparation for re-use, recycling, recovery, neutralization. It means that the municipal waste management must be based, most of all, on selective collection of wastes and on recycling, including fractions which have been weakly used so far, among others bio-degradable wastes. These relatively new goals enforce re-assessment of already planned and performed investments in the field of possibilities to perform them and efficiency of commenced municipal waste management reform. In Poland, the changes in question in a great scale started in 2013 , after amendment of a law enabling communes to manage wastes and making them responsible for performance of estimated goals. It resulted in, among others, concentration of direct investments in the area of waste management, financed from treasury and Union's funds, private and public ones. Investment plans and already performed investments show that no proceedings hierarchy has been observed and hence, it may cause competition of particular investments for access to wastes and potential import of certain fractions. As a result it will decrease efficiency of certain installations and it may cause failure to follow required recycling rates; consequently, the Union may impose sanctions on Poland for failure to fulfill its obligations. The aim of the paper is to indicate that the waste targets, as a tool of circulate economy requires appropriate waste treatment installations. However, the selection of these installations should be made at the state level, because leaving the choice to the investor does not secure technical possibilities to achieve the objectives of municipal waste management, neither in terms of quantity nor cost. The paper follows a case study approach. The paper is based on the analysis of existing and planned waste treatment installations in Poland in relation to the quantity and composition of waste generated by households. The further part of the article is a discussion whether the existing and planned investment directions are in line with the accepted waste target and allow for their achievement at the lowest possible investment outlays. 


\section{Introduction}

For couple of years Poland has not been managing produced municipal wastes. Most of the wastes were sent to (waste) yards and a selective collection at source has been unknown in practice. A lot of changes in this field have been enforced from the moment of "wastes revolution" in 2013 and obligation to carry out selective municipal waste collection (Monitor Polski 2016, poz. 784). In order to follow new regulations, there have been erected, among others, new installations and wastes processing plants. Funds originated mainly from public finances (central budget, budgets of voivodships, communes and poviats), target funds (national and voivodship environment protection funds and water management fund) as well as from abroad. Positive effects of the changes in question are noticeable but it is necessary to verify their efficiency at the domestic level and to assess meeting of assumed goals of the circular economy as a determinant of actions in the field of the municipal waste management. Specificity of the municipal waste management sector and financing it from public finances to the large extent makes that market regulation mechanisms are limited and it is necessary to control proper allocation of the resources.

\section{Waste taryet as tool of circular economy - legal basis}

Basic assumptions of the circular economy were prepared by the European Commission in 2015 (COM/2014/0398 final/2). The main one is conversion of wastes into resources by performance of proceedings hierarchy regarding wastes, in particular:

- stimulation of best practices in this field,

- development of innovative recycling technologies,

- reduction of (waste) yards,

- development of stimulants encouraging consumers to change their behaviors (COM (2017) 34 final).

In order to monitor progress of performance of the goals in question, particular quantity goals were developed and entered into European Union's law, among others into a frame directive on wastes (Dz.U. UE L z 22 listopada 2008) as well as in domestic laws, in Poland in the act on wastes (Dz.U. 1996, nr 132, poz. 622). They have also been transposed into the Domestic Waste Management Plan 2022 (KPGO 2022) (Szpadt, 2010), which is a determinant for development of the Polish waste management system for incoming years. As quantity goals, which could be a sort of circular economy performance rates ${ }^{1}$, the following ones have been assumed:

a) recycling rate and preparation for re-use of resources fraction ${ }^{2}-\min .50 \%$ of their mass by $2020 ;{ }^{3}$

b) share of mass of thermally processed municipal wastes originating from processing of municipal waste, in relation to produced municipal wastes must not exceed $30 \%$;

c) by 2025 at least $60 \%$ of communal waste must be recycled;

d) by 2030 at least $65 \%$ of communal waste must be recycled (COM (2017) 34 final);

e) reduction of municipal waste landfill up to max. $10 \%$ by 2030 ;

f) reduction of municipal waste subject to bio-degradation, addressed to the waste yards, in such a way that in 2020 no more than 35\% mass of such waste is stored in relation to mass of waste produced in 1995.

${ }^{1}$ When calculating percentage values one needs to include all municipal wastes received and collected (also building wastes originating from households), information from Monitor Polski 2016, poz. 784.

${ }^{2}$ Municipal waste (paper, metals, plastics and glass).

${ }^{3}$ New accepted European Commission's proposals command achieving 75\% rate by 2030 . 
Entries of the partnership agreement (COM/2014/0397 final - 2014/0201 (COD)), which is basis of the financial perspective of the European Union 2014-2020 repeat the quantity goals and declare allocation of the financial means for development of system of wastes selective collection, assuring collection of waste to be recycled, taking steps intended to change behaviors of people in the field of proper segregation of wastes "at the root", increase in use of already existing economic instruments promoting proper collection and management of wastes, and development of installations designed to sort wastes collected selectively. These entries are accordant with Union's entries on financing of the entire circular economy pack. The most important regulations are:

- public support for projects goal of which is anticipation of a crisis of deliveries and reduction of European Union dependency on strategic resources import,

- achievement of a synergy between social benefits and economic reliability of financed projects,

- support for projects assuring technological innovations,

- approval of support for non-technological innovations (business innovations, social and organizational ones) (Assessment..., 2015).

Simultaneously, certain operational goals were reserved. Namely, erection of yards is permitted only in justified cases, especially in case of non-recyclable hazardous wastes, and erection of new installations intended to incinerate residue wastes (incineration plants, MBP installation) is possibly only if there is no risk to erect excess infrastructure and hierarchy of wastes is observed totally (COM/2014/0398 final/2).

\section{Generation of municipal waste and treatment plants in Poland}

Official data on quantity of produced waste seem to be underestimated. It results that quantity of produced wastes has been falling down step by step, despite growing GDP (3-4\% annually) and minor drop of quantity of inhabitants (from 2010 number of inhabitants dropped by approx. 100 thousand) (GUS, 2017). Such a relation has not been achieved by any developed country. Moreover, in Poland we produce nearly 2 times less waste per inhabitant. At the same time, $2 \mathrm{M} \mathrm{Mg}$ of wastes are found at illegal (waste) yards (GUS, 2016). It is shown at the fig. hereunder.

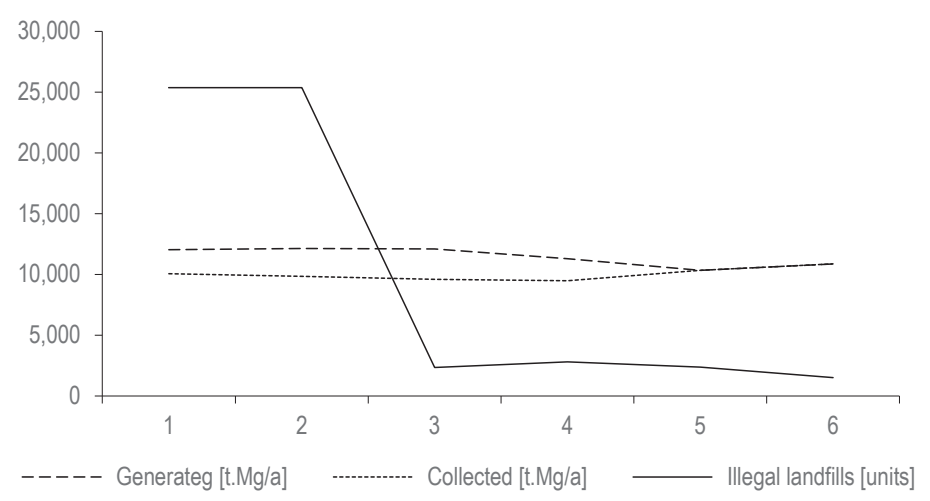

Figure 1. Generated wastes, collected [thousands Mg/annually] and illegal landfills 2010-2015

Source: own materials based on GUS' data, Environment Protection 2016. 
Hence, forecasts of wastes produced in 2030 must equal 14-15 M Mg/a (Styś, Foks, Moskwik, 2016), and not, as it results from estimations based on the GUS' data, approx. $12 \mathrm{M} \mathrm{Mg/a.}{ }^{4}$

Many years in Poland no municipal waste management was performed and, from 2010 no. of installations other than yards, has been growing up. Nevertheless, yards still are being erected. In 2010 (waste) yards could accept more than $1 \mathrm{M} \mathrm{Mg} / \mathrm{a}$, and in 2013 nearly 800 thousand Mg, in 2014 - 200 thousand Mg, and in 2015 - 400 thousand Mg From 2012, performance of the solid wastes composting installation has been growing at the rate approx. 400 thousand $\mathrm{Mg}$ annually (with exception of 2013 when the annual grow equaled approx. 100 thousand $\mathrm{Mg}$ ). From 2014 to 2015 there occurred municipal wastes incinerating plants and their total performance equals approx. 118 thousand Mg/a. From 2013, there also has been growing up performance of installations intended to liquidate wastes in a way other than biologically or thermally, by approx. 230-300 thousand Mg/a. There also has been growing up performance of devices intended to use the municipal waste, from approx. 120-150 thousand $\mathrm{Mg}$ (2010-2012) up to 600-700 thousand Mg/a from 2013-2015. performance of installations put to operation, in form of percentage, is presented in the Figure 2.

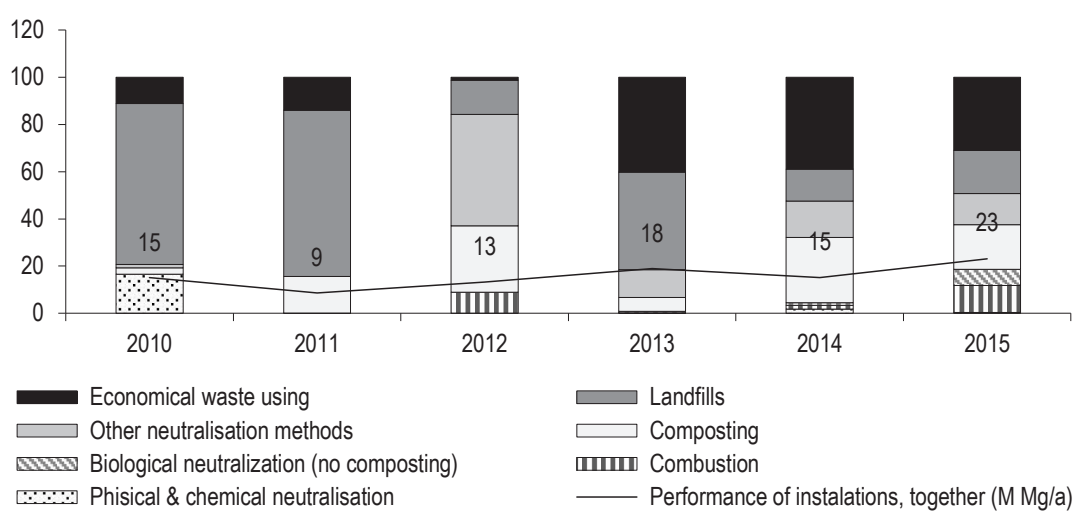

Figure 2. Performance of municipal waste treatment installations, put to operation from 2010 to 2015 (\%)

Source: own materials based on GUS' data, Environment Protection 2016.

Simultaneously, from 2010 to 2015 there were erected varied types of installations without clear trends in this field. Annual growth of performance of all installations shows clear growth tendency and it fluctuates from 1 to 1.5-2 (2013-2015) M Mg/a.

Mostly, investors in undertakings in the municipal waste management are companies, however, invested capital originates mainly from public funds. The following graph demonstrates share of fixed capital formation originating

${ }^{4}$ In 2022 all forecasts were based on official data and min. \& max. variants were approved. For 2025 the following values were approved 11,797,074.11 Mg/annually and 11,399,956.8 Mg/annually, and for 2030, 12,280,372.2 and 11,682,021.6 Mg/annually (Szpadt, 2010). 
from public funds. ${ }^{5}$ Total fixed capital formation allocated to investments into municipal waste management show constant progress, from PLN 700 M in 2010 to 3 B in 2015.

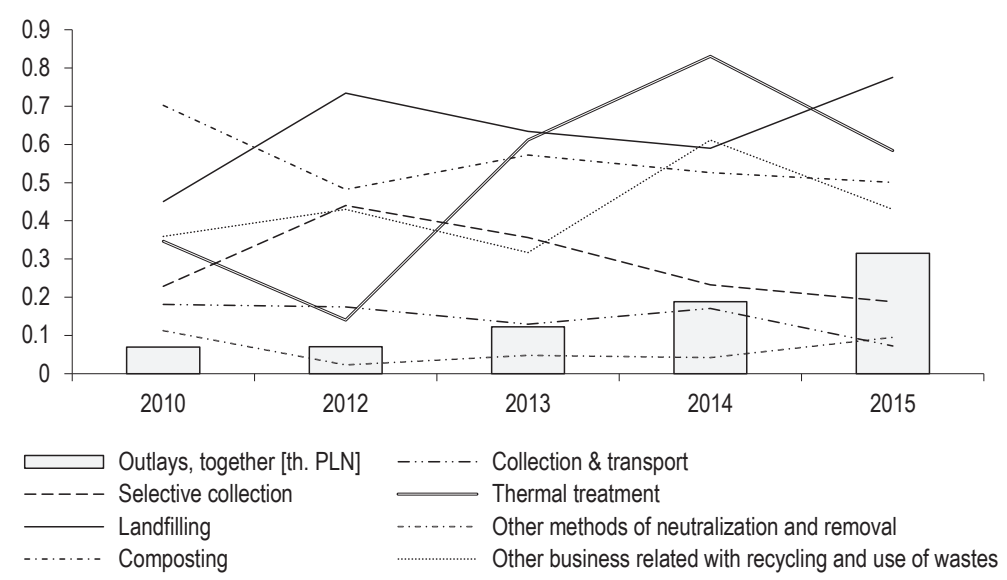

Figure 3. Share of public funds in finances intended for fixed capital formation in the waste management 2010-2015 (\%)

Source: own elaboration on the grounds of GUS [Main Statistical Office], Environment Protection, 2016.

The highest share of public funds in finances intended for fixed capital formation ${ }^{6}$, at $60-80 \%$ level, is assigned to landfills and waste thermal processing installations. Share of public funds in investments related with composting installations equals $50-60 \%$. Transport of wastes and selective collection are characterized by share of public funds at the approx. 10-20\% level (in particular from 2014 to 2015), and other methods of liquidation (with exemption of composting) approx. 5-10\%. Only in case of selective collection of municipal wastes, share of public funds went down by half, from approx. $40 \%$ in 2012 to approx. 20\% in 2015. In case of remaining business related with recycling and use of wastes, including municipal wastes, share of public funds has been growing up, from approx. 30-40\% (2010-2013) to approx. 50-60\% (2014-2015). Taking ownership structure in companies into account (frequently $100 \%$ held by communes), share of public means may be even higher.

\section{Availability of particular fractions of municipal wastes in a context of circular economy goals}

In order to determine supply of municipal wastes in the perspective of 2030 it is necessary to determine quantity of produced wastes and their morphology as well. Because of described problems regarding estimation of produced wastes, min. variant was accepted that is $12 \mathrm{M} \mathrm{Mg}$ annually (KPGO 2022) and max. $15 \mathrm{M} \mathrm{Mg}$. Quantities of particular fractions were estimated on the grounds of morphological content established in KPGO 2022 (Szpadt, 2010). The amounts in question are entered into Table 1.

\footnotetext{
${ }^{5}$ Resources originating from the treasury (central budget, budgets of voivodships, communes and poviats), target funds (national and voivodship environment protection funds and water economy) as well as from abroad.

${ }^{6}$ Acc. to GUS' methodology, fixed capital formation means purchase of lands (including perpetual usufruct), buildings and premises, civil engineering structures (including building \& mounting works, design and cost assessment documents), technical equipment and machinery, means of transport, devices, movables and equipment.
} 
Table 1. Potential availability of particular fractions of municipal wastes in a forecast for 2030 , variant min. and max. (Mg)

\begin{tabular}{lrrrr} 
& \multicolumn{1}{c}{ Min. } & \multicolumn{1}{c}{ Max. } & Min. & Max. \\
\cline { 2 - 5 } Quantity of Generated Waste & $12,000,000.00$ & $15,000,000.00$ & & \\
Paper and Cardboard & $1,363,825.20$ & $1,704,781.50$ & & \\
Glass & $1,205,733.60$ & $1,507,167.00$ & bio (no paper) & $5,089,797.84$ \\
Metals & $271,122.00$ & $338,902.50$ & & \\
Plastics & $1,470,224.40$ & $1,837,780.50$ & & \\
\hline Multi-Material & $417,747.60$ & $522,184.50$ & & $5,485,426.50$ \\
Kitchen and Garden & $3,887,817.60$ & $4,859,772.00$ & & \\
Mineral & $503,337.60$ & $629,172.00$ & including green ones & $4,388,341.20$ \\
<10 mm & $1,171,830.00$ & $1,464,787.50$ & & \\
Textiles & $315,392.40$ & $394,240.50$ & & \\
\hline Wood & $50,224.80$ & $62,781.00$ & & \\
Hazardous & $90,266.40$ & $112,833.00$ & & \\
Other & $500,685.60$ & $625,857.00$ & (raw mat.) & $4,310,905.20$ \\
Large-Dimensions & $251,269.20$ & $314,086.50$ & & \\
Green Areas & $500,523.60$ & $625,654.50$ & & \\
\hline
\end{tabular}

Source: own material based on Szpadt (2010).

At such assumptions, in 2030 Poland will have a resource fraction in quantity between 4.3 a $5.3 \mathrm{M} \mathrm{Mg} / \mathrm{a}$ (Dz.U. 2016, poz. 1987). Quantity of bio-degradable wastes, which can be produced7 equals from 5 to $6.3 \mathrm{M} \mathrm{Mg} / \mathrm{a}$, from which approx. 4.4 to $5.5 \mathrm{M} \mathrm{Mg} / \mathrm{a}$ are green wastes. ${ }^{8}$ Bio-degradable wastes comprise clothes and textiles and wood $-50 \%$, multi-material packages $-40 \%$, fraction $<10 \mathrm{~mm}-30 \%$ and wastes originating from kitchen and green areas.

Following the hierarchy of proceeding with wastes, as a superior rule of the circular economy, the most substantial way to process already produced municipal wastes is recycling. In 2025 it must equal at least $60 \%$ and in $2030-65 \%$ of produced wastes. This quantity comprises both, material recycling and biologic recycling. Simultaneously, recycling must include post-package wastes at 50\% rate in 2020 of produced waste quantity (of this type), and $75 \%$ in 2030 . Hence, in case of $60 \%$ of municipal waste recycling (variant 1.1 ), recycling will include 7.2-9 M Mg wastes (in case of produced waste accordingly 12 and $15 \mathrm{M} \mathrm{Mg}$ ). In case of $65 \%$ of required recycling (variant 1.2.) it will be, accordingly, 7.8-9.7 M Mg/a. If we assume that recycling must include $50 \%$ of postpackage wastes it will be accordingly 2.1 and $2.7 \mathrm{M} \mathrm{Mg}$ and it means that biologic recycling (or potentially, along with large dimensions wastes) in variant 1.1. it must equal $\min .5-6.3 \mathrm{M} \mathrm{Mg}$, and in case of variant 1.2. 5.6-7 Mg. Nevertheless, if recycling of post-package wastes is accepted (following the European Commission) at the $75 \%$ level, then it will equal accordingly 3.2-4 M Mg, and recycling of remaining wastes must equal min. $4.5-5.7 \mathrm{M} \mathrm{Mg}$. After including goals regarding recycling, for other processing ways there will be left 4.8-6 M Mg (with assumption of $60 \%$ recycling) or $4.2-4.5 \mathrm{M} \mathrm{Mg}$ (with assumption of $65 \%$ recycling). These estimations have been entered into Table 2.

\footnotetext{
${ }^{7}$ Bio-degradable wastes comprise clothes and textiles and wood $-50 \%$, multi-material packages $-40 \%$, fraction $<10 \mathrm{~mm}-30 \%$ and wastes originating from kitchen and green areas.

${ }^{8}$ Wastes originating from kitchen and green areas.
} 
Table 2. Quantity goals of circular economy for Poland (Mg/a)

\begin{tabular}{|c|c|c|c|}
\hline \multirow{3}{*}{ Hierarchy/variants } & \multirow{2}{*}{ Processes } & \multicolumn{2}{|c|}{ Goals of Circular Economy } \\
\hline & & $\min$. & $\max$. \\
\hline & quantity of waste & $12,000,000.00$ & $15,000,000.00$ \\
\hline 1.1. & recycling of municipal waste - material and biologic $(60 \%)$ & $7,200,000.00$ & $9,000,000.00$ \\
\hline \multirow{2}{*}{ 1.1.1. } & including material recycling (min.) 50\% (KPGO 2022) & $2,155,452.60$ & $2,694,315.75$ \\
\hline & including biologic recycling & $5,044,547.40$ & $6,305,684.25$ \\
\hline \multirow{2}{*}{ 1.1.2. } & including material recycling (min.) $75 \%$ (KE) & $3,233,178.90$ & $4,041,473.63$ \\
\hline & including biologic recycling & $3,966,821.10$ & $4,958,526.38$ \\
\hline 1.2. & recycling of municipal waste - material and biologic ( $65 \%)$ & $7,800,000.00$ & $9,750,000.00$ \\
\hline \multirow{2}{*}{ 1.2.1. } & including material recycling (min.) 50\% (KPGO 2022) & $2,155,452.60$ & $2,694,315.75$ \\
\hline & including biologic recycling & $5,644,547.40$ & $7,055,684.25$ \\
\hline \multirow{2}{*}{ 1.2.2. } & including material recycling (min.) $75 \%$ (KE) & $3,233,178.90$ & $4,041,473.63$ \\
\hline & including biologic recycling & $4,566,821.10$ & $5,708,526.38$ \\
\hline 2.1. & after the recycling $(60 \%)$ & $4,800,000.00$ & $6,000,000.00$ \\
\hline 2.2 . & after the recycling $(65 \%)$ & $4,200,000.00$ & $5,250,000.00$ \\
\hline 3. & max. to ITPOK $(30 \%)$ & $3,600,000.00$ & $4,500,000.00$ \\
\hline 4. & max landfill $-10 \%$ & $1,200,000.00$ & $1,500,000.00$ \\
\hline
\end{tabular}

Source: own work.

Wastes after the recycling process may be combusted or landfilled but their quantity is reduced. Quantity of wastes and residues after processing of wastes addressed to thermal processing must not exceed $30 \%$ of produced wastes' mass. However, wastes and their residues addressed to the landfills must not exceed $10 \%$ of produced wastes' mass. In this way maximal quantities of wastes addressed to thermal processing plants may equal 3.6 to $4.5 \mathrm{M} \mathrm{Mg}$, and into landfills $-1.2-1.5 \mathrm{M} \mathrm{Mg}$.

\section{Assessment of investment decisions for meeting objectives of circular economy}

For proper achieving of goals, investments must be relevantly adjusted in terms of performance and processing way. Till 2014 Poland was characterized by $15.5 \mathrm{M} \mathrm{Mg}$ performance of sorting plants, $14.4 \mathrm{M}$ of performance MBP installations and solid waste composting plants (including $9.4 \mathrm{M} \mathrm{Mg}$ processing capability of the mechanical part) and RDF combustion performance up to $1.5 \mathrm{M} \mathrm{Mg/a}$ and total (completed investments and investments under construction) performance of municipal waste incinerating plants equal $1 \mathrm{M} \mathrm{Mg} / \mathrm{a}$. These quantities are set out in Table 3.

In 2015, to the largest extent, MBP installations' performance went down, by nearly 600 thousand Mg and performance of landfills - by more than 400 thousand Mg. Performance of all of the installations, at the end of 2015 equaled $39.4 \mathrm{M} \mathrm{Mg} / \mathrm{a}$. At the analyzed period there were also carried out installations for commercial use of municipal waste. In 2015 they managed to increase their performance by 716 thousand Mg, achieving totally $2.3 \mathrm{M} \mathrm{Mg} / \mathrm{a}$.

Legitimacy of completed investments must be considered in form of opportunity to perform circular economy's goals adjusted to quantity of manufactured wastes and simultaneous consideration of costs of such investments. This assessment does not include legal barriers and opportunities to obtain wastes limiting performance of particular actions, just potential technical and financial possibilities. Comparing capital expenditures from 2012 to 2015 it could be concluded that the highest average unit costs is shown by incinerating plants, nearly PLN 6000/Mg, while costs 
Table 3. Performance of municipal waste treatment plants in Poland till 2015 (Mg/annually)

\begin{tabular}{|c|c|c|c|c|}
\hline Installations & \multicolumn{2}{|c|}{ KPGO 2022 - to 2014} & GUS 2015 & Total 2015 \\
\hline Sorting plants mixed & \multicolumn{2}{|l|}{$1,840,000.00$} & & \\
\hline Sorting plant selective & $2,840,000.00$ & $15,580,000.00$ & $304,676.00$ & $15,884,676.00$ \\
\hline Sorting plant selective + mixed & \multicolumn{2}{|l|}{$10,900,000.00$} & & \\
\hline Mechanical & \multicolumn{2}{|l|}{$9,400,000.00$} & & \\
\hline Biologic & $4,100,000.00$ & $14,370,000.00$ & $596,267.00$ & $14,966,267.00$ \\
\hline Composting plants & \multicolumn{2}{|l|}{$870,000.00$} & & \\
\hline Cement mills (RDF) can be $1.5 \mathrm{M}$ & \multirow{2}{*}{\multicolumn{2}{|c|}{$\begin{array}{l}1,100,000.00 \\
1,000,000.00\end{array}$}} & & \\
\hline Incineration plants & & & $261,930.00$ & $2,361,930.00$ \\
\hline Landfills & \multicolumn{2}{|c|}{$5,790,909.09$} & $423,278.00$ & $6,214,187.09$ \\
\hline \multirow[t]{2}{*}{ Machinery designed to use municipal waste for economic purposes } & - & - & 716531.00 & 2350850.00 \\
\hline & Total & $32,050,000.00$ & $1,586,151.00$ & $39,427,060.09$ \\
\hline Economical waste using & & & & $2,350,850.00$ \\
\hline
\end{tabular}

Source: own material based on GUS, Environment protection 2009-2016, KPGO 2022 (Programowanie..., 2015).

of thermal processing plants is lower - PLN 3.8 thousand/Mg. These are many times more expensive installations than the remaining ones hence, they should be carried out only when no other solutions exist. From among other types of installations the highest costs are shown by landfills - PLN 655/Mg of performance, the cheapest one by solid waste composting plants - PLN 503/Mg of performance. Average cost of other wastes liquidation plants equals approx. PLN 600. Worth of mentioning is that costs of devices designed for industrial use of wastes are lower - averagely PLN 520/Mg. Average unit costs of particular types of installations are shown in Table 4.

Table 4. Average unit costs of installations carried out in Poland from 2012 to 2015

\begin{tabular}{lccc}
\hline \multicolumn{1}{c}{ Instalation/proces } & Efficiency (Mg/y) & Outlays (th. PLN) & Unit cost (PLN/Mg) \\
\hline Neutralisation (no composting) & $1,573,072.0$ & $941,558.8$ & 599.0 \\
Composting & $1,334,033.0$ & $670,907.0$ & 503.0 \\
Combusting & $405,448.0$ & $2,399,839.6$ & $5,919.0$ \\
Landfills & $1,598,897.0$ & $1,047,584.4$ & 655.0 \\
Economy using of waste & $2,078,987.0$ & $1,080,883.3$ & 520.0 \\
\hline
\end{tabular}

Source: own material based on GUS' data, Environment protection.

Assuming that in waste sorting plants (collected selectively) $30 \%$ of wastes are recycled, and in waste sorting plants (mixed), 30\% raw material waste are recovered, Poland, at the end of 2015 had nearly $13.4 \mathrm{M} \mathrm{Mg}$ of processing power (effective power). This quantity is increased by approx. 6.5\% of processing plants of mechanical part of MBP installation, that is by $600,000 \mathrm{Mg} / \mathrm{a}$. Maximal quantity of produced raw material wastes in Poland in 2030 will equal $5.4 \mathrm{M} \mathrm{Mg}$. Goals to be performed show necessity to recycle materials (2-4 M Mg depending on material). Hence, performed investments show at least double excess in relation to a need.

Bio-degradable waste in 2030 in Poland there will be manufactured maximally at quantity 5-6.3, and green waste $-4.4-5.5 \mathrm{M} \mathrm{Mg} / \mathrm{a}$. Performance of goals enforces biologic recycling at the 5-6 M Mg level. Power of MBP installations, in biologic part and in composting plants, equals approx. $5 \mathrm{M} \mathrm{Mg}$, from which solid waste composting 
plants are characterized by performance equal approx. $1 \mathrm{M} \mathrm{Mg} / \mathrm{a}$. This is too small quantity to achieve established goals. In particular, it is necessary to increase installations, which can process green waste and waste originating from kitchens.

Poland may finally incinerate $4.5 \mathrm{M} \mathrm{Mg} / \mathrm{a}$ and landfilled $1.5 \mathrm{M} \mathrm{Mg} / \mathrm{a}$. Temporarily, Poland has landfills which can collect $6.2 \mathrm{M} \mathrm{Mg} / \mathrm{a}$ in case of assumption that $60-70 \%$ of produced waste is landfilled. ${ }^{9}$ After deduction of obligatory recycling and landfill that is $10 \%$, still $3-4.5 \mathrm{M} \mathrm{Mg} /$ a wastes are to be disposed. Assuming that $30 \%$ of power of MBP mechanical part is RDF fuel, then, $3 \mathrm{M} \mathrm{Mg}$ of waste can be intended for incineration. Mixed waste incineration plants use the remaining quantity of waste, $1 \mathrm{M} \mathrm{Mg} / \mathrm{a}$. Hence, a problem is no installations to incinerate RDF, in quantity approx. 1.5 M Mg/a.

\section{Conclusions}

From the previous content it results that selection of erected installations is relatively random. For sure, adjusting them to meet goals of the circular economy is not a key decision when making investment decisions. Also costs efficiency is not taken into account in terms of the macro-economy. Cost optimization is made at the investor level and selection of type of an installation, at the regions level (RIPOK) or a commune level. Such an approach does not warrant effective allocation of public funds and meeting Union's goals, The most frequently, Polish system of municipal waste management is compared to German one and similar solutions are suggested. However, the German system is mature one while Polish system just has been launched. Beginnings of both of the systems were based on other assumptions, hence, their development paths must be different. For sure, Poland needs to use effect of the late start. Nevertheless, it is still taking place to a limited extent. Still solid waste sorting plants and landfills have been developed which is characteristic for undeveloped systems (Ciechelska, 2014), instead of effective investments in a waste liquidation system, not only by means of direct investments.

\section{Referenences}

Assessment of access-to-finance conditions for projects supporting Circular Economy, Final report (2015). Innov Fin Advisory, European Investment Bank Advisory Services, Luxembourg. Retrieved from: /www.eib.org/attachments/pj/access_to_finance_ study_on_circular_economy_en.pdf.

Ciechelska, A. (2014). Rozwój systemów gospodarki odpadami komunalnymi. Analiza stopnia zrównoważenia polskiego systemu gospodarki odpadami komunalnymi. In: B. Bartniczak, K. Trzeciak (eds.), Współczesne uwarunkowania zarządzania środowiskiem. Jelenia Góra: Wydawnictwo Ad Rem.

Dyrektywa Parlamentu Europejskiego i Rady 2008/98/WE z dnia 19 listopada 2008 r. w sprawie odpadów oraz uchylająca niektóre dyrektywy, Dz.U. UE L z dnia 22 listopada 2008 r., z późn. zm.

GUS (2016). Ochrona środowiska.

GUS, liczba ludności maleje już piąty rok z rzędu (2017). Retrieved from: www.bankier.pl/wiadomosc/GUS-Liczba-ludnosci-Polskimaleje-juz-piaty-rok-z-rzedu-3699007.html.

Komunikat Komisji do Parlamentu Europejskiego, Rady, Europejskiego Komitetu Ekonomiczno-Społecznego i Komitetu Regionów, Ku gospodarce o obiegu zamkniętym: program „zero odpadów dla Europy” / COM/2014/0398 final/2 */, http://eur-lex.europa.eu/ legal-content/PL/TXT/HTML/?uri=CELEX:52014DC0398R(01)\&from=PL.

Komunikat Komisji do Parlamentu Europejskiego, Rady, Europejskiego komitetu Ekonomiczno-społecznego i Komitetu Regionów, Znaczenie Przetwarzania odpadów w energię w gospodarce o obiegu zamkniętym, Bruksela, 26.01.2017, COM (2017) 34 final.

${ }^{9}$ This efficiency will grow up along with reduction of stored waste. 
Programowanie perspektywy finansowej 2014-2020 Umowa Partnerstwa (2015). Ministerstwo Rozwoju, Warszawa, grudzień. Retrieved from: https://www.funduszeeuropejskie.gov.pl/media/14132/_Umowa_Partnerstwa_zmieniona_012016.pdf (15.06.2017).

Styś, T., Foks, R., Moskwik, K. (2016). Raport: Krajowy plan gospodarki odpadami 2030. Instytut Sobieskiego. Retrieved from: www. sobieski.org.pl/wp-content/uploads/Stys-Foks-Moskwik-KPGO-2030-PDF.pdf.

Szpadt, R. (2010). Prognoza zmian w zakresie gospodarki odpadami. Kamieniec Wrocławski. Retrieved from: file://C:/Users/User/ AppData/Local/Packages/Microsoft.MicrosoftEdge_8wekyb3d8bbwe/TempState/Downloads/111-2010.pdf.

Uchwała nr 88 Rady Ministrów z dnia 1 lipca 2016 r. w sprawie Krajowego planu gospodarki odpadami 2022, Monitor Polski z 2016, poz. 784 , wraz z załącznikiem

Ustawa z dnia 13 września 1996 r. o utrzymaniu czystości i porządku w gminach, Dz.U. nr 132, poz. 622, z późn. zm.

Ustawa z dnia 14 grudnia 2012 r. o odpadach, Dz.U. 2016, poz. 1987, z późn. zm.

Wniosek Dyrektywa Parlamentu Europejskiego i Rady zmieniająca dyrektywy 2008/98/WE w sprawie odpadów, 94/62/WE w sprawie opakowań i odpadów opakowaniowych, 1999/31/WE w sprawie składowania odpadów, 2000/53/WE w sprawie pojazdów wycofanych z eksploatacji, 2006/66/WE w sprawie baterii i akumulatorów oraz zużytych baterii i akumulatorów i 2012/19/UE w sprawie zużytego sprzętu elektrycznego i elektronicznego /* COM/2014/0397 final - 2014/0201 (COD) */.

Cite this article aS: Ciechelska, A. (2018). Effectiveness of investments in municipal waste management in Poland in the context of goals of the circular economy. European Journal of Service Management, 3 (27/2), 85-94. DOI: 10.18276/ejsm.2018.27/2-11. 